\title{
TRADO-MODERN COMMUNICATION STRATEGIES FOR EFFECTIVE IMPLEMENTATION OF COMMUNITY DEVELOPMENT PROGRAMMES IN BAYELSA STATE, NIGERIA
}

\author{
Gilpin Morgan ${ }^{*}{ }^{\circledR}$ iD , M.E. Hanachor ${ }^{1}$, Professor M.A. Oyebamiji ${ }^{1}$ \\ ${ }^{* 1}$ Department of Adult and Non-Formal Education, Faculty of Education, University of Port \\ Harcourt, Nigeria
}

DOI: https://doi.org/10.29121/granthaalayah.v9.i3.2021.3709

Article Type: Research Article

Article Citation: Gilpin Morgan, M.E. Hanachor, and Professor M.A. Oyebamiji. (2021). TRADO-

MODERN COMMUNICATION

STRATEGIES FOR EFFECTIVE

IMPLEMENTATION OF

COMMUNITY DEVELOPMENT

PROGRAMMES IN BAYELSA STATE,

NIGERIA. International Journal of

Research -GRANTHAALAYAH, 9(3),

109-117.

https://doi.org/10.29121/granthaa

layah.v9.i3.2021.3709

Received Date: 26 February 2021

Accepted Date: 25 March 2021

Keywords:

Trado-Modern Communication

Strategies

Implementation

Community Development

Programmes

\section{ABSTRACT}

This study examined trado-modern communication strategies for effective implementation of community development programmes in Bayelsa State, Nigeria. Two objectives and two research questions guided the study. The study adopted descriptive survey and exploratory research designs. 405 respondents were adopted as sample size through total enumeration sampling. A structured questionnaire titled "Trado-Modern Communication Strategies for Effective Implementation of Community Development Programmes" (QT-MCSIECDP) with $r=0.82$ was used for data collection. The instrument was validated by experts from the Department of Adult and Non-Formal Education in the University of Port Harcourt, Nigeria. Data were analysed using frequency, percentage and mean statistics. Results show that traditional rulers, groups, town-criers, face-to-face interaction and village squares are the available trado-modern communication channels for effective implementation of community development programmes in Bayelsa State; trado-modern communication keeps the communities up-to-date and enables individuals to react knowledgeably and intelligently to the environment, communicates feelings, creates acceptable changes in behaviour, boosts information, shows ways to solve problems and further growth for effective implementation of community development programmes in Bayelsa State. The study recommended among others that traditional rulers, town-criers, groups, village square and face-to-face interaction should always be used to inform, convince and motivate the community citizens for effective implementation of community development programmes.

\section{INTRODUCTION}

Information plays an important role in almost every human activity. Its value in the development process cannot be over emphasised. Indeed, information dissemination and accessibility have reduced the world to a global village. Bayelsa State, like the rest of the world, is experiencing change in all aspects of life from basic cultural values to technology, which has changed not only the mode of communication but also the concept of time. In Bayelsa State, there are different methods of providing information for the people. These are the traditional methods and the modern methods.

(C) 2021 The Author(s). This is an open access article distributed under the terms of the Creative Commons Attribution License, which permits unrestricted use, distribution, and reproduction in any medium, provided the original author and source are credited. 
Trado-Modern Communication Strategies for Effective Implementation of Community Development Programmes in Bayelsa State, Nigeria

The rural dwellers of Bayelsa State who are accustomed to an oral tradition relate to the information exchanged in the way they understand. Meyer $(2000,2003)$ identifies communication mechanisms and information seeking behaviour typical of people who are used to an oral tradition. The manner in which information is communicated is largely determined by whether the community will react to it or not. For example, if information is not offered in metaphorical speech or demonstrated in a way the people are used to, the people will not be able to understand it and it will not make any impression on them. Phrasing and repetition are used to ensure that critical expressions are stored in the memory. Phrasing provides the basis for an agreed upon interpretation, which may go beyond what was actually said. Language is employed in specialised contexts for particular purpose and authority structures role in storing and transferring information. The implication is that if authorities are not familiar with a particular type of outside information, the information will not be easily sanctioned and his will not easily be accepted by the group.

Among Bayelsans in the rural communities, information is exchanged face-to-face. Information cannot be transmitted over long distances. Often information remains within the borders of a particular community. Unless the people of different communities interact, information created in other communities will remain inaccessible. Stories and myths tend to be experiential, that is, based on events familiar to the listener or story-teller. Mnemonic aids such as rhymes are widely used to make oral transfer of information more reliable. Recipe-like patterns or stereotypical methods of expression are also very common. Unnecessary repetition may be used to ensure that information is conveyed correctly and in detail. Bayelsans in the rural communities also have their own particular way of handling information that is closely related to their social and cultural background. Meyer (2000) discusses research on information used by rural people in a study of a group of traditional farmers producing food for their consumption; incoming information was better understood and accepted in a way which they could identify. They exchanged information through "indigenous communication mechanism" and most members had little exposure to ways of communicating that are based primarily on literacy. The situation described by Meyer is typical of the rural and urban communities of Bayelsa State.

In rural communities in Bayelsa State, information is provided most noticeably in oral communication pattern. In almost all rural communities, town-criers and their activities are noticeable. They use wooden or metal gongs or drums to stir up the people and deliver messages daily. Another means of oral provision of information is holding meetings. Most villages and towns have squares or town-halls where the people meet to discuss issues and make decisions. Through this means they provide information for their well-being and development. The rural population is mostly illiterate and they get information this way at no cost. The oral exchange of information indicates that rural dwellers have been able to relate to information exchange in the way they are accustomed to. Information is also stored in people's memories and the people with good memories play a vital role in storing and transferring information. The death of a knowledgeable person may lead to valuable information being lost. Traditional rulers, juju priests, chief priests, soothsayers, village chiefs and elders, story-tellers and diviners play key roles as information providers in the rural traditional context.

The colonisation of Nigeria by the British brought with it a different or alien ways of providing information but the traditional ways are still strongly adhered to by the people. Many communities of Bayelsa State have no electricity and electric power generators served as substitute. A microphone in a central position (radio house) and loudspeakers placed in different locations in the communities ensure that town criers cover a wide range without moving from their positions. Matters handled and settled by traditional courts, council of elders and chiefs are communicated to the entire community. A loser in a case must have to pay to the radio house operator (town-crier) a fee for the decisions reached to be announced to the entire community. Obituaries, gatherings, meetings, kings' (Ebena-owei and Amanana-owei) messages and other announcements are disseminated through this medium. Notable communities where these loudspeakers can easily be seen are Amassoma in Southern Ijaw Local Government Area, Ogobri and Ofoni in Sagbama Local Government Area and Opolo-Epie and Agudama-Epie in Yenagoa Local Government Area, all in Bayelsa State.

Mchombu (1995), Mazie and Ghelfi (1995) describe the important positive relationship between information and development. Information is a critical resource for people in both rural and urban areas. Solutions to the numerous issues that have afflicted the rural communities in Bayelsa State, therefore are embodied in the need for development which is seen as a process of change to improve the living conditions of the people. Different problems such as poor orientation, low mobilisation, apathy, ineffective communication, low funding, poor planning and coordination have seriously inhibit the people from participating and solving development issues affecting them. Though the government of Bayelsa has been trying to encourage active participation in community development in 
the rural communities, the general lukewarm attitude among the rural dwellers still persists. Some observers of community development efforts in Bayelsa State have specifically attributed this tepid attitude of the people to the communication process adopted for the mobilisation of the people over the years.

More often than not, too, the rural dwellers in Bayelsa State do not understand the language used by the development planners and communicators because it is highly specialised and technical. As a result, vital issues and concepts are misunderstood or misinterpreted by the rural dwellers and those implementing policies, thereby creating a gap between the communicators of the development information and the meaning derived by the target audience (Neil, 2002). Consequently, the rural dwellers are not adequately informed about opportunities that abound within and outside their locality. The need, therefore, arises to further persuade them to take practical steps towards harnessing opportunities to better their lot. The notion of rural mobilisation operates on the premise that the people living at the periphery, where poverty, hunger, disease and sundry socio-economic vices are more pronounced, need to participate in development programmes and projects with a view to improve the quality of their lives (Nwodu, 2007).

There is the need for adequate and effective mobilisation of all stakeholders that will be involved in the life cycle of the community development process for effective people's participation in community development programmes in the rural areas. The process will start from need identification, planning, resource mobilisation, monitoring, implementation, evaluation, feedback and utilisation. According to Neil (2002), for community development activities to be effective, the mobilisation of the people must be based on assessment of available communication resources within the community. However, information dissemination methods that are based on traditional definitions of literacy do not work well for rural dwellers of Bayelsa State who are used to an oral tradition. In providing information for Bayelsa State, information providers should access and recognise their target groups and devise the best means to disseminate meaningful information for sustainable development to such groups. Understanding this assertion is the concept and belief that the people know where their shoes pinch; they know what is best for them. No expert can better understand and appreciate the people and the community development problems than the people themselves and the communities. No one, no group can liberate or develop the people. The people must bake the development cake themselves and unless the people themselves are the driving force of their own development, no amount of investment will bring any lasting improvements in their living standards.

A realistic communication strategy for the rural communities in Bayelsa State is, therefore, a prerequisite for implementing community development programmes and it will commence with the input of the target communities to improve their circumstances. In addition, the communication activity should involve psychology, motivation or persuasion than rhetorics and coercion of change agents. Quarmyne (1990) states that the strategy demands communication competence, that is, the ability to reflect upon and articulate the key factors, problems, needs and interests of communities. The fact contained in this assertion has not been in doubt since the start of development communication as a field of study. Traditional methods are still effective and providers can use modern communication media to boost information as well.

Adopting traditional and modern means of communication in rural areas has been advocated by many communication scholars, who are intensely concerned on how each of these communication systems could complement or integrate to enhance effective rural communication that will propel rural development Traditional and Modern Means of Communication, 2015). The interaction between two complementary media brings out something greater than what both of hem could have achieved had they worked separately (Akinleye, 2002). To this extent, the desire for establishing rational and dynamic links between trado-modern communication and overall development goals of the rural communities of Bayelsa State should be associated with improvement of living standards, process in education, culture, scientific and technological spheres. The desire involves social, political, economic and other material requirements of the communities (McBride, 1980). The government of Bayelsa State and its agencies can utilise trado-modern communication channels for propagating development messages and ideas for rural development.

The use of the traditional media can obtain sustainable results, demonstrate impact and create an institutional base in the development projects or programmes. This is based on the principles that every human communication is not only peculiar in some respects but also has some unique resources that are always useful in solving whatever problem it may have and in furthering growth. They can exploit the local means, materials and methods, songs and dances, games, fables and puppet shows (Traditional Means of Communications, 2010). They are realistic and based on the daily lives of ordinary people, they can communicate attitudes, beliefs, values and feelings in powerful ways, they do not require understanding that comes with modern education in the majority of instances; they can indicate 
problems of community life, they can motivate people to change their behaviour and they can show ways to solve problems. Local traditional events are usually popular and they can be sad, serious or happy. They are easily understood and they usually cost little or no money. They reflect a people's culture they are not introduced to the people like the mass media but they are part of the people (Nwabueze, 2007). All they require is imagination and practice.

The modern communication media, newspapers, magazines, radio, television, cinema, and so on, have their own attractions. Immediacy is one of their greatest advantages, especially broadcast media since they allow for on-thespot account of the day intelligence (Okon, 2010). The speed of the modern media could be helpful in times of emergencies when they can be used in reporting stories that require immediate attention. They also keep the society abreast and fresh through news reports which enable individuals to react knowledgeably and intelligently to their environment. They interpret and convey information on demographic issues, strength and weakness of the economy, problems facing a nation, achievements of a nation in different sectors and so on. The use of the modern media and interpersonal communication channels by individuals in creating and sharing information with one another is poor. Information is often misinterpreted, creating unnecessary confusion and tension among the rural communities and community members. The state government has to divert its meager resources to quell riot, insurrection and uprising in the rural communities. Consequent upon this, the rural populace lacks the enabling environment for awareness, knowledge and opinion to reach a mutual understanding.

The prevailing communication process increases lack of interest of the people to be mobilised for community development programmes. As it were, the people do not understand vital issues that can further growth and development and they are also not able to react knowledgeably and intelligently to the environment. To find out how trado-modern communication strategies can bring about effective implementation of community development programmes in Kolokuma/Opokuma and Ekeremor Local Government Areas of Bayelsa State is the problem of the study.

\section{OBJECTIVES OF THE STUDY}

The objectives of this study are to:

1) Identify the available trado-modern communication channels for effective implementation of community development programmes in Bayelsa State.

2) Establish the relevance of trado-modern communication in the implementation process of community development programmes in Bayelsa State.

\section{RESEARCH QUESTIONS}

The following research questions guided the study:

1) What are the available trado-modern communication channels for effective implementation of community development programmes in Bayelsa State?

2) What is the relevance of trado-modern communication in the implementation of community development programmes in Bayelsa State?

\section{METHODOLOGY}

The study adopted descriptive survey and exploratory research designs. The population for this study comprised 405 community members from five registered groups in Kolokuma/Opokuma and Ekeremor Local Government Areas of Bayelsa State, Nigeria. The entire population (four hundred and five) respondents were adopted as sample size through total enumeration sampling. The research instrument used for this study was a structured questionnaire titled "Trado-Modern Communication Strategies for Effective Implementation of Community Development Programmes" QT-MCSEICDP). The instrument was in two sections A and B. A gave background information about the respondents while section B was designed to obtain information on tradomodern communication strategies for effective implementation of community development programmes. The questionnaire items were developed based on mkodified four-point Likert rating of Stongly Agree $(\mathrm{SA})=4$ points, 
Agree (A) = 3 points, Disagree (D) 2 points and Strongly Disagree (SD) = 1 point. The instrument was validated by two experts in the area of measurement and evaluation in the Department of Adult and Non-Formal Education in the University of Port Harcourt, Nigeria. A test-retest method was used to ensure the reliability of the instrument at 0.82 . Data were analysed using frequencies and simple percentages for demographic characteristics of the respondents while the mean statistics was used for analysing research questions.

\section{RESULTS}

\subsection{ANALYSES OF DEMOGRAPHIC CHARACTERISTICS}

\begin{tabular}{|c|c|c|c|}
\hline Characteristics & Age Group & Frequency & Percentage (\%) \\
\hline & $18-25$ & 22 & 5.4 \\
\hline & $26-35$ & 75 & 18.5 \\
\hline Age & $36-45$ & 162 & 40 \\
\hline & $46-55$ & 102 & 25.2 \\
\hline & $56-65$ & 27 & 6.7 \\
\hline & $66-$ above & 17 & 4.2 \\
\hline & Total & 405 & 100 \\
\hline Educational Qualification & WASC/GCE/SSCE & 167 & 41,2 \\
\hline & Diploma & 102 & 25.2 \\
\hline & Degree & 136 & 33.6 \\
\hline & Total & 405 & 100 \\
\hline & Civil Servants & 206 & 50.9 \\
\hline & Business & 31 & 7.7 \\
\hline Occupation & Farmers & 133 & 32.8 \\
\hline & Others & 35 & 8.6 \\
\hline & Total & 405 & 100 \\
\hline
\end{tabular}

Table 4.1 shows that $40 \%$ of the respondents were between 36 and 45 years and $25.2 \%$ were between 46 and 55 years, meaning that most of the respondents are in their prime age. The least number of respondents are between 18-25 years (5.4\%) and 66 above (4.2\%). Table 4.2 shows that majority of the respondents with a frequency of 102 $(25.2 \%)$ and 136 (33.6\%) have acquired post secondary school education, with a minimum of a diploma. Other respondents have school certificate with a frequency of $167(41.2 \%)$ This means that their response level is reliable. Table 4.3 reveals that $50.9 \%$ of the respondents are civil servants constituting a higher frequency of the population for the study. They are followed by farmers with $32.8 \%$. The respondents in business and others are $7.7 \%$ and $8.6 \%$ respectively.

\section{ANALYSES OF THE RESEARCH QUESTIONS}

Research Question 1: What are the available trado-modern communication channels for effective implementation of community development programmes.

Table 1: Available trado-modern communication channels for effective implementation of community development programmes in Bayelsa State.

\begin{tabular}{|c|c|c|c|c|c|}
\hline s/n & items & Responses & $\begin{array}{c}\text { Total } \\
\mathrm{N}=405\end{array}$ & $\begin{array}{c}\text { Mean } \\
(\mathrm{x})\end{array}$ & Decision \\
\cline { 2 - 6 } & & $\mathrm{SA} \mathrm{A} \mathrm{D}$ SD & & & \\
\hline 1. & $\begin{array}{c}\text { My traditional ruler plays a key role as information } \\
\text { provider in my community. }\end{array}$ & $\begin{array}{c}231 \quad 109 \quad 6 \quad 59 \\
(924)(327)(12)(59)\end{array}$ & $\begin{array}{c}405 \\
(1322)\end{array}$ & 3.26 & Available \\
\hline
\end{tabular}


Trado-Modern Communication Strategies for Effective Implementation of Community Development Programmes in Bayelsa State, Nigeria

\begin{tabular}{|c|c|c|c|c|c|}
\hline 2. & $\begin{array}{l}\text { Groups play a vital role as information providers in } \\
\text { my community. }\end{array}$ & $\begin{array}{cccc}190 & 203 & 6 & 6 \\
(760) & (609) & (12) & (6)\end{array}$ & $\begin{array}{c}405 \\
(1387)\end{array}$ & 3.42 & Available \\
\hline 3. & $\begin{array}{l}\text { Information is exchanged through face-to-face } \\
\text { interaction in my community }\end{array}$ & $\begin{array}{cccc}206 & 165 & 34 & 0 \\
(824) & (495) & (68) & (0)\end{array}$ & $\begin{array}{c}405 \\
(1387)\end{array}$ & 3.42 & Available \\
\hline 4. & $\begin{array}{c}\text { The town-crier (or radio house) is an important } \\
\text { medium for transfer of information in my } \\
\text { community. }\end{array}$ & $\begin{array}{cccc}324 & 68 & 8 & 5 \\
(1296) & (204) & (16) & (5)\end{array}$ & $\begin{array}{c}405 \\
(1521)\end{array}$ & 3.76 & Available \\
\hline 5. & $\begin{array}{l}\text { The village square (or town hall) is an important } \\
\text { venue for transfer of information in my community. }\end{array}$ & $\begin{array}{ccrc}197 & 188 & 9 & 11 \\
(788) & (564) & (18) & (11)\end{array}$ & $\begin{array}{c}405 \\
(1381)\end{array}$ & 3.41 & Available \\
\hline & Grand Mean & 3.46 & & & \\
\hline
\end{tabular}

Table 1 above shows that the respondents are positive on all the items as the weighted mean score is greater than the criterion mean of 2.50. This indicates that the traditional ruler of each community plays a key role as information provider in their communities as illustrated with a mean score of 3.26; groups play a vital role as information providers in their communities with a weighted mean of 3.42; information is exchanged through faceto-face interaction in their communities, 3.42. Similarly, the respondents affirmed that the town-crier (or radio house) is an important medium for transfer of information in their communities with a mean of 3.76; and the village square (or town hall) is an important venue for transfer of information in their communities with a mean of 3.41. The grand mean of 3.46 is greater than the criterion mean of 2.50. This result indicates that these are the available trado-modern communication channels for effective implementation of community development programmes in Bayelsa State

Research Question 2: What is the relevance of trado-modern communication in the implementation process of community development programmes in Bayelsa State.

Table 2: Relevance of trado-modern communication in the implementation process of community development programmes in Bayelsa State.

\begin{tabular}{|c|c|c|c|c|c|}
\hline $\mathrm{s} / \mathrm{n}$ & Items & Responses & $\begin{array}{c}\text { Total } \\
\mathrm{N}=405\end{array}$ & $\begin{array}{c}\text { Mean } \\
(\mathrm{x})\end{array}$ & Decision \\
\hline & & $\begin{array}{cccc}\begin{array}{c}\text { SA } \\
\text { (x4) }\end{array} & \text { D } & \text { SD } \\
(\mathrm{x} 2) & (\mathrm{x} 1)\end{array}$ & & & \\
\hline 1. & $\begin{array}{l}\text { An integration of traditional with } \\
\text { modern communication will communicate } \\
\text { feelings in powerful ways in my community }\end{array}$ & $\begin{array}{l}260 \quad 98 \quad 41 \quad 6 \\
(1040)(294)(82) \\
(6)\end{array}$ & $\begin{array}{c}405 \\
(1422)\end{array}$ & 3.51 & Agree \\
\hline 2. & $\begin{array}{c}\text { An integration of traditional with modern } \\
\text { communication can motivate the people of the } \\
\text { community towards acceptable changes in } \\
\text { behaviour. }\end{array}$ & $\begin{array}{l}229132 \quad 359 \\
(916)(396)(70) \\
(916)\end{array}$ & $\begin{array}{c}405 \\
(1391)\end{array}$ & 3.43 & Agree \\
\hline 3. & $\begin{array}{l}\text { An integration of traditional with modern } \\
\text { communication will boost information for } \\
\text { implementation of development programmes in my } \\
\text { community. }\end{array}$ & $\begin{array}{l}253 \quad 138 \quad 14 \quad 0 \\
(1012)(414)(28) \\
(0)\end{array}$ & $\begin{array}{c}405 \\
(1454)\end{array}$ & 3.59 & Agree \\
\hline 4. & $\begin{array}{l}\text { An integration of traditional with modern } \\
\text { communication will show ways to solve problems } \\
\text { and further growth in my community }\end{array}$ & $\begin{array}{l}241 \quad 124 \quad 15 \quad 25 \\
(964)(372)(30) \\
\\
(25)\end{array}$ & $\begin{array}{c}405 \\
(1391)\end{array}$ & 3.43 & Agree \\
\hline 5. & $\begin{array}{l}\text { An integration of traditional with modern } \\
\text { communication will show ways to solve problems } \\
\text { and further growth in my community. }\end{array}$ & $\begin{array}{l}265 \quad 92 \quad 24 \quad 24 \\
(1060)(276)(48) \\
(24)\end{array}$ & $\begin{array}{c}405 \\
(1408)\end{array}$ & 3.48 & Agree \\
\hline & Grand Mean & 3.49 & & & \\
\hline
\end{tabular}


Table 2 above shows that the respondents agreed to all the items and each weighted mean is greater than the criterion mean of 2.50. This result indicates that an integration of traditional with modern communication can keep their communities up-to-date and enable individuals react knowledgeably and intelligently to the environment, communicate feelings in powerful ways in their communities towards acceptable changes in behaviour, boost information for implementation of development programmes in their communities, and show ways to solve problems and further growth in their communities with means of 3.51, 3.43, 3.50, 3.48 respectively. On the average, a mean score of 3.49 was recorded, which is greater than the criterion mean of 2.50. This implies that trado-modern communication has relevance in the implementation of community development programmes in Bayelsa State.

\section{DISCUSSION OF FINDINGS}

Research question one reveals that traditional rulers, groups, face-to-face interaction, town-criers and village squares are the available trado-modern communication channels for effective implementation of community development programmes in Bayelsa State. This finding corroborates Ogwezzy in James (2015) who agrees that town-criers are the traditional announcers of community's news, decisions, instructions, laws and many other issues of the community to the people. They act as broadcasting stations of contemporary time. They are designated honourary official announcers of their communities and announce what has been agreed upon. The system is still active in rural African societies.

As pointed out by Nwuneli in James (2015), most of the information disseminated by a town-crier originates from some authoritative sources such as Emir, Oba, Council of Elders, and so on. It is any of these authoritative sources that determine the content of the town-crier's message. Also, face-to-face, interpersonal and group communication channels function both vertically and horizontally and are natural, real and inevitable in a community's planned and unplanned advancement (Haider, 2005).

Research question two reveals that trado-modern communication keeps communities up-to-date and enables individuals to react knowledgeably and intelligently to the environment. For effective implementation of community development programmes in Bayelsa State. This is in line with Osho (2010) who notes that trado-modern communication provides the rural communities with necessary knowledge. For instance, trado-modern communication does not overlook the fact that learning primarily consists of self-expression and self-education. It also focuses on rural issues and the problems of the rural communities, but amazingly rural population has no say at all. A system has to be invented in which communication will take into account the views of the majority of the rural population communication has to be decentralised and the rural community has to actually participate in managing organs of communication.

\section{CONCLUSION}

A lot of work and attention need to be given to the study of trado-modern communication systems. Not much is gained by the system if the pronouncements of government officials are not attended by concrete action. For example, it is fashionable for government information chiefs to make pronouncements in rural communities about the need to utilise and fund the 'town-criers' who knows rural communities. When the actual funding is called for, it is Western mass media hardware that funds are usually provided for in the budget. If governments are serious about making the traditional system more effective and serve the interests of the central government, money must be provided for the improvement of the central government, money must be provided for the improvement of traditional media.

In order that the traditional newsman may not be confused with ubiquitous drug peddlers who use the mounted loudspeakers, some special attention must be given to the improvement of his mobility and his hardware. As one of the most credible sources of information for the rural areas, no attempt should be made to vitiate the quality of the service rendered by the traditional newsman in the name of innovation. Therefore, all efforts at modernisation should be made with the custodians of the society fully involved in all the processes that may lead to some changes. Furthermore, improvements may be made but the essence of the system that selects a town-crier development process as such attitude in the past has destroyed many valuable aspects of our culture. 


\section{RECOMMENDATION}

Based on the findings of this study, the following recommendations were made:

1) Traditional rulers, town-criers, groups, village square and face-to-face interaction should always be used to inform, convince and motivate the people for effective implementation of community development programmes.

2) There should be proper integration of the use of traditional communication with modern communication for effective implementation of community development programmes in the rural areas.

\section{SOURCES OF FUNDING}

This research received no specific grant from any funding agency in the public, commercial, or not-for-profit sectors.

\section{CONFLICT OF INTEREST}

The author have declared that no competing interests exist.

\section{ACKNOWLEDGMENT}

None.

\section{REFERENCES}

[1] Akinleye, L. (2002). Indigenous knowledge system, communication and sustainable development. In E.0. Soola (Ed.) Communicating for development purposes. Ibadan, Kraft Books Limited.

[2] Comparative study of the usage of traditional and modern means of communication (2015) <http//www.scharticles.com/role-of-mass-media-in-grassroot-development> October 5, 2016.

[3] Haider, M. (2005). Global public communication: Challenges, perspective and strategies. Boston MA; Jones and Barlett Publishers.

[4] James, A.J. (2015). Influence of trado-modern media on health campaigns in rural areas. Journal of new media and mass communication, 3(4), $57-62$.

[5] MacBride, S. (1980). Many voices, one world. Ibadan, Ibadan University Press.

[6] Mazie, S.M. \& Ghelfi, I.M. (1995). Challenges of the rural environment in a global economy. Library trends, $4(1), 7-20$.

[7] Mc hombu, K.J. (1995). Researching rural information provision: A case study proceedings of the seminar on information provision to rural communities in Africa. Goborone, Botswana Uppsala University Library.

[8] Meyer, H.W. (2000). The transfer of agricultural information to rural communities. Unpublished doctoral dissertation, University of Pretoria, Pretoria, South Africa.

[9] Meyer, H.W. (2003). Information use in rural development. The new review of information behaviour research. 4, 109-126.

[10] Neil, J.T. (2002). Social support helps people grow. Horizons, 17 (Springs) $32-34$.

[11] Nwabueze, C.D. (2007). Role of the traditional media in grassroots mobilisation and poverty reduction for sustainable human development. I.E. Nwosu, N.T. Fab-Ukozor \& L.C. Nwosu (Eds.) Communication for sustainable human development. Enugu, African Council for Communication Education, ACCE, 3(1), 63 $-70$.

[12] Nwodu, L.C. (2007). Managing development communication campaign for sustainable human development. I.E. Nwosu, N.T. Fab-Ukuzor \& L.C. Nwodu (Eds.). Communication for sustainable human development. Enugu, African Council for communication Education, ACCE, 3(1), $42-46$. 
[13] Okon, G. (2010). Trado-modern media mix for sustainable rural development in Nigeria. E.O. Soola, H.E. Batta, C.D. Nwabueze (Eds.) Communication and Africa's development crisis. VDM Verlag Dr. Muller Gmb and Co. KG, 31 - 39.

[14] Osho, S. (2010). African communication system. Abeokuta, ESS-OH Consult.

[15] Quarmyne, W. (1990). Towards a more participatory communication environment: Cross-linking establishment and alternative media. Communication process: Alternative channels and strategies for development support. Canada: IDRC, $1-10$.

[16] Traditional means of communication (2016). < mobile.digital- campus.org >course $>$ oppiacontent $>$ CHWSworldwide>HEALMI >0ctober, 5, 2016. 